\title{
Pengaruh Ekstrak Anggur Laut terhadap pH Lambung dan duodenum pada Rattus norvegicus Jantan yang Diinduksi Indometasin
}

\author{
Ardilon Raxel Faruwu ${ }^{1}$, Riami ${ }^{2}$, Fitri Handajani ${ }^{3 *}$ \\ Fakultas Kedokteran, Universitas Hang Tuah Surabaya ${ }^{1}$ \\ Departemen Biokimia, Fakultas Kedokteran Universitas Hang Tuah Surabaya ${ }^{2}$ \\ Departemen Anatomi, Fakultas Kedokteran Universitas Hang Tuah Surabaya ${ }^{3}$ \\ *e-mail: fitrihandajanidr@gmail.com
}

\begin{abstract}
Abstrak
Indometasin merupakan obat antiinflamasi nonsteroid (NSAID) yang berkerja menghambat COX-1. Penghambatan COX-1 mengakibatkan penghambatan produksi prostaglandin. Prostaglandin adalah regulator sekresi buffer asam lambung. Hambatan prostaglandin mengakibatkan penurunan $\mathrm{pH}$ lambung dan duodenum dan merusak lambung dan duodenum. Anggur laut (Caulerpa racemosa var. cylindracea) merupakan makroalga yang memiliki kandungan flavonoid sebagai antioksidan dan antiinflamasi. Tujuan penelitian ini untuk mengetahui pengaruh anggur laut terhadap $\mathrm{pH}$ lambung dan duodenum rattus norvegicus jantan yang diinduksi indometasin. 32 ekor Rattus norvegicus jantan dibagi menjadi 4 kelompok. Kelompok K (-) tanpa perlakuan. Kelompok K (+) diinduksi indometasin $30 \mathrm{mg} / \mathrm{Kg} \mathrm{BB}$ selama 7 hari. Kelompok P1 diinduksi indometasin 30mg/Kg BB selama 7 hari dilanjutkan pemberian ekstrak anggur laut $1 \mathrm{~g} / 100 \mathrm{~g} B \mathrm{~B}$ selama 14 hari. Kelompok $\mathrm{P} 2$ diinduksi indometasin $30 \mathrm{mg} / \mathrm{Kg}$ BB selama 7 hari dilanjutkan pemberian ekstrak anggur laut $2 \mathrm{~g} / 100 \mathrm{~g}$ BB selama 14 hari. Pada hari ke-29 seluruh hewan coba dikorbankan, lambung dan duodenum diambil serta diukur pH cairannya. Hasil uji One-way Anova didapatkan nilai $\mathrm{p}=0,023$. Uji Post Hoc pada $\mathrm{pH}$ lambung didapatkan perbedaan rerata pada kelompok $\mathrm{K}(-)$ dengan $\mathrm{K}(+)$ dengan nilai $\mathrm{p} 0,005$ dan kelompok K (-) dengan P2 dengan nilai p 0,020. pH duodenum hasil uji post hoc didapatkan bahwa tidak terdapat perbedaan yang bermakna pada semua kelompok. Pemberian ekstrak anggur laut tidak menunjukkan perbedaan $\mathrm{pH}$ lambung dan duodenum secara bermakna pada tikus yang diinduksi indometasin.
\end{abstract}

Kata Kunci: indometasin, COX-1, prostaglandin, bikarbonat, pH lambung, gastritis

\section{Effect of Sea Grape Extract on Gastric and Duodenal pH in Male Rattus norvegicus Induced by Indomethacin}

\begin{abstract}
Indomethacin is a nonsteroidal anti-inflammatory drugs (NSAIDs) that act to inhibit COX-1. The inhibition of COX-1 leads to inhibition of prostaglandin production. Prostaglandin is a regulator of gastric acid buffer secretion. Inhibition of prostaglandin decrease gastric and duodenum $\mathrm{pH}$ and damage the gastric and duodenum. Sea grapes (Caulerpa racemose var. cylindracea) are marcoalgae that contain flavonoids as antioxidants and anti-inflammatory. The aim of this study was to determine the effect of sea grapes on gastric and duodenum $\mathrm{pH}$ in rattus norvegicus induced by indomethacin. 32 male Rattus norvegicus were divided into 4 groups. Group K (-) without treatment. Group K (+) was induced by $30 \mathrm{mg} / \mathrm{Kg}$ BW indomethacin for 7 days. Group $P 1$ was induced by $30 \mathrm{mg} / \mathrm{Kg}$ BW indomethacin for 7 days followed by
\end{abstract}


Pengaruh Ekstrak Anggur Laut terhadap pH Lambung dan duodenum pada Rattus norvegicus... Ardilon Raxel Faruwu, Riami, Fitri Handajani

administration of $1 \mathrm{~g} / 100 \mathrm{~g}$ BW sea grape extract for 14 days. Group P2 was induced by $30 \mathrm{mg} / \mathrm{Kg}$ BW indomethacin for 7 days followed by administration of $2 \mathrm{~g} / 100 \mathrm{~g}$ BW sea grape extract for 14 days. On the $29^{\text {th }}$ day, rats were terminated, gastric and duodenal were isolated then the fluid $\mathrm{pH}$ was measured. One-way Anova test obtained $p=0,023$. Post hoc test $\mathrm{pH}$ Gaster significantly different between group $K(-)$ and $K(+)(p=0,005)$ and between group $K(-)$ with $P 2(p=0,020)$. While in group $K(+)$ with $P 1$ and $P 2$ there was no significant difference in $\mathrm{pH}$. Post hoc test of $\mathrm{pH}$ duodenum showed no differences in all group. The administration of sea grape extract did not show a differences of the gastric and duodenal $\mathrm{pH}$ significantly between rats induced by indomethacin.

Keywords: indomethacin, $\mathrm{COX}-1$, prostaglandin, bicarbonate, gastric $\mathrm{pH}$, duodenal $\mathrm{pH}$ gastritis

\section{PENDAHULUAN}

Gastritis merupakan penyakit yang sering dialami masyarakat luas. Gastritis terjadi akibat kerusakan pada mukosa lambung akibat reaksi inflamasi yang berkembang menjadi luka atau peptik ulser. Gastritis dapat juga dapat disebabkan oleh berbagai agen perusak seperti, infeksi bakteri, terpapar bahan yang terlalu asam, alkohol, obat NSAIDs (non-steroidal Antiinflammatory Drugs). Secara fisiologis, lambung memiliki berbagai mekanime pertahanan untuk melawan agen perusak. Mekanisme pertahanan pre-epitel secara umum tersusun atas lapisan mukosa yang mengandung mukus, bikarbonat, dan fosfolipid permukaan yang mencegah sel epitel dari agen perusak seperti asam lambung. Prostaglandin meregulasi sekresi bikarbonat dan mukus, menghambat sekresi asam lambung yang penting dalam mempertahankan restitusi sel epitel dan aliran darah mukosa (Matsui et al, 2011). Apabila mekanisme pertahanan ini terganggu, dapat menyebabkan kerusakan pada mukosa lambung yang disebabkan oleh sekresi asam lambung yang berlebihan, juga oleh agen perusak lainnya. Kerusakan ini dapat berkembang menjadi ulser memicu reaksi inflamasi. Bila iritasi berlanjut tidak hanya lambung saja yang akan mengalami kerusakan namun juga berdampak pada kerusakan duodenum. (Tarique et al, 2016).

Non-steroidal Anti-inflammatory Drugs (NSAIDs) ini sering diresepkan diantaranya aspirin dan indometasin. Aspirin dan indometasin merupakan obat paling umum terhadap arthritis, inflamasi dan proteksi kardiovaskular. Selain itu NSAIDs juga dapat menyebabkan komplikasi pada gastrointestinal seperti ulser dan erosi (Matsui et al, 2011). Obat ini bekerja dengan cara menghambat Cyclooxygenase (COX). COX adalah suatu reseptor enzim prostaglandin yang berperan menimbulkan rasa nyeri. COX-1 banyak ditemukan pada sel endotel, sel epitel lambung dan platelet. Sebaliknya COX-2 hanya terdapat pada beberapa jaringan. COX-2 terbentuk akibat 
adanya induksi inflamasi (Drini, 2017). Penggunaan obat NSAIDs dapat mengganggu sistem pertahanan serta dapat memicu terjadinya kerusakan pada lambung. NSAID, seperti indometasin, pada dosis antara 150$200 \mathrm{mg} /$ hari dapat menghambat produksi prostaglandin (PG), serta meningkatkan motilitas lambung, menghasilkan peningkatan permeabilitas mukosa juga menyebabkan terjadinya infiltrasi neutrofil dan produksi oxyradical. Jika infiltrasi neutrofil dan produksi oxyradical berlangsung terus menerus dapat menimbulkan lesi lambung (Laine et al, 2008; Amrulloh dan Utami, 2016).

Algae hijau, coklat atau pun merah ekstraknya dapat diperoleh melalui proses fraksionasi atau dimurnikan. Proses fraksinasi dapat menghasilkan hasil metabolit yang dapat menghambat bakteri, virus, jamur dan epibion lainnya diantaranya adalah sebagai: cytostatic, antivirus, antihelmintik, antibakteri, aktivitas antijamur. Selain itu juga bersifat sebagai antioksidan, antikanker dan antiinflamasi (Pérez et al, 2016). Pemeriksaan fitokimia

\section{BAHAN DAN METODE}

\section{Alat dan Bahan Penelitian}

Sebanyak 32 ekor Rattus norvegicus jantan yang dipilih secara random. Hewan coba diperoleh dari Laboratorium Biokimia Universitas Hang Tuah Surabaya yang pada Caulerpa racemosa dilaporkan mengandung senyawa bioaktif fenol, tanin, flavonoid, dan alkaloid, gallokatekin, epikatekin dan katekin. Antioksidan merupakan senyawa - senyawa turunan fenol (Djapiala et al, 2013). Caulerpa racemosa mengandung berbagai macam antioksidan seperti protoklorofilide, beta karoten, dan senyawa-senyawa polifenol (flavonoid, lignin. Tannin). Caulerpa racemosa mengandung metabolit caulerpin berperan sebagai anti-nociceptive dan antiinflamasi. Ridhowati dan Asnani (2016) melaporkan bahwa pemberian cauleprin secara oral pada mencit mampu menurunkan nosisepsi oleh asam asetat tanpa mengubah aktivitas motorik. Selain itu, dapat menurunkan defek formalin pada konsentrasi $35,4 \%$ dan $45,6 \%$, aktivitas antiinflamasinya sebesar 55,8\%. Berdasarkan teori tersebbut, penelitian ini bertujuan untuk mengetahui efek dari pemberian ekstrak anggur laut (Caulerpa racemosa var. cylindracea) terhadap $\mathrm{pH}$ lambung dan duodenum Rattus norvegicus gastritis diinduksi indometasin.

kemudian diadaptasi selama 7 hari. Sampel dibagi menjadi 4 kelompok, masing masing terdiri dari 8 ekor yaitu: kelompok kontrol negatif (K-) tanpa perlakuan. Kelompok kontrol positif $(\mathrm{K}+)$ diberi Indometasin dengan dosis $30 \mathrm{mg} / \mathrm{kg}$ BB per hari. Kelompok P1 diberi Indometasin dengan 
Pengaruh Ekstrak Anggur Laut terhadap pH Lambung dan duodenum pada Rattus norvegicus... Ardilon Raxel Faruwu, Riami, Fitri Handajani

dosis $30 \mathrm{mg} / \mathrm{kg} \quad B B$ dan dilanjutkan pemberian ekstrak anggur laut dosis $1 \mathrm{~g} / 100 \mathrm{~g}$ BB selama 14 hari. Kelompok P2 diberi Indometasin dengan dosis $30 \mathrm{mg} / \mathrm{kgBB}$ dan dilanjutkan pemberian ekstrak anggur laut dosis $2 \mathrm{~g} / 100 \mathrm{~g}$ BB selama 14 hari. Pemberian indometasin melalui sonde intragastrik $1 \mathrm{x} /$ hari di pagi hari sebelum makan selama 7 hari.

\section{Pembuatan ekstrak anggur laut}

Ekstrak anggur laut dibuat menggunakan metode maserasi, ebanyak 8 $\mathrm{kg}$ anggur laut segar yang ditimbang kemudian dicuci bersih dan dipotong kecil lalu dimaserasi menggunakan bahan pelarut etanol 60\%. Maserasi dilakukan selama 24 jam, maserat dipisahkan dengan cara disaring dan proses maserasi diulang dua kali dengan jenis pelarut dan jumlah pelarut yang sama. Hasil maserasi dimasukkan ke dalam cawan porselin lalu diletakkan diatas waterbath untuk diuapkan agar didapatkan ekstrak yang lebih kental.

\section{Cara pengukuran pH Lambung dan}

duodenum

Hewan coba dikorbankan dengan anastesi kemudian Lambung dan duodenum dikeluarkan dari abdomen. Selanjutnya diinjeksikan $\mathrm{NaCl}$ 0.9\% $3 \mathrm{~mL}$ ke dalam lambung, sama halnya dengan duodenum. Kemudian bagian kurvatura mayor dibedah dan cairan lambung diambil, kemudian dimasukan ke dalam tabung dan disentrifuse dengan kecepatan $3000 \mathrm{rpm}$ selama 10 menit. Hal yang sama dilakukan pada cairan duodenum, kemudian mengambil cairan bening di atas endapan dengan mikropipet lalu dipisahkan untuk diukur $\mathrm{pH}$ cairan menggunakan $\mathrm{pH}$-meter merk starter 300 (Suhartri et al, 2008).

\section{HASIL}

Data hasil penelitian ini di tunjukkan rerata $\mathrm{pH}$ lambung dan $\mathrm{pH}$ duodenum antar kelompok pada Gambar 1.

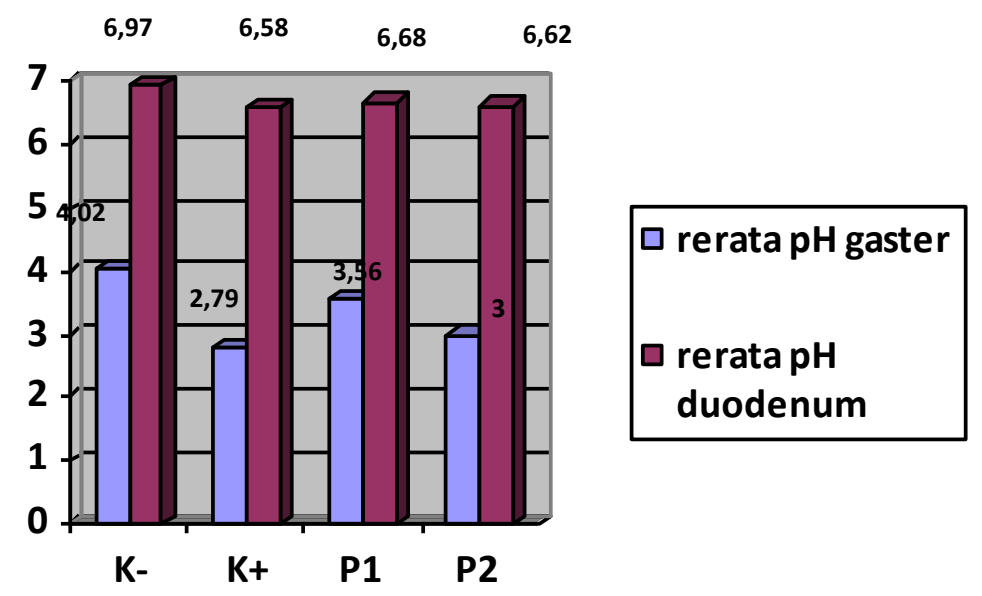


Gambar 1. Rerata pH Lambung dan pH duodenum antar kelompok

Hasil penelitian menunjukan nilai pemberian ekstrak anggur laut (Caulerpa rata-rata $\mathrm{pH}$ lambung terendah yaitu sebesar racemosa var. cylindracea).

\section{2,79 terdapat pada kelompok $\mathrm{K} \quad(+)$} sedangkan nilai rata-rata $\mathrm{pH}$ lambung tertinggi terdapat pada kelompok $\mathrm{K}(-)$ yaitu sebesar 4,02. Sebaliknya, rerata $\mathrm{pH}$ lambung pada kelompok P1 yaitu sebesar 3,56 dan P2 sebesar 3 memiliki pH diatas $\mathrm{k}(+)$ setelah
Hasil Uji One Way Anova

$\begin{array}{lll}\text { Hasil uji } \text { One-way } & \text { Anova } \\ \text { menunjukkan nilai } \mathrm{p}=0,023 & \text { yang } \\ \text { menunjukkan terdapat } & \text { perbedaan } & \text { yang } \\ \text { bermakna antar kelompok., sedangkan hasil } & \\ \text { uji post hoc dapat diamati pada Tabel } 1 .\end{array}$

Tabel 1. Uji Post Hoc pH lambung dan duodenum Rattus norvegicus yang diinduksi indometasin

\begin{tabular}{cccc}
\hline Kelompok (I) & Kelompok (J) & pH Lambung & pH duodenum \\
\hline K (-) & K (+) & $0,005^{*}$ & $0,008^{*}$ \\
& P1 & 0,273 & $0,040^{*}$ \\
K (+) & P2 & 0,020 & 0,022 \\
& P1 & 0,069 & 0,472 \\
P1 & P2 & 0,598 & 0,646 \\
& P2 & 0,185 & 0,792 \\
\hline
\end{tabular}

Hasil uji Post Hoc terhadap $\mathrm{pH}$ lambung menunjukkan perbedaan bermakna antara kelompok K (-) dengan $\mathrm{K}(+)$ dengan nilai $\mathrm{p}=0,005$ kelompok $\mathrm{K}(-)$ dengan $\mathrm{P} 1$ dengan nilai $p=0,273$. pada $K(-)$ dengan $P 2$ menunjukkan nilai $p=0,02$, antara kelompok $K(+)$ dengan P1 dengan nilai $p=0,069$, antara kelompok $\mathrm{K}(+)$ dengan P2 dengan nilai $p=0,598$, antara kelompok P1 dan P2 dengan nilai $=0,185$, menunjukkan tidak terdapat perbedaan secara bermakna.

Hasil uji Post Hoc terhadap $\mathrm{pH}$ duodenum menunjukkan perbedaan bermakna antara kelompok K (-) dengan K
(+) dengan nilai $\mathrm{p}=0,008$ dan kelompok $\mathrm{K}(-)$ dengan P1 dengan nilai $p=0,040$. Antara K (-) dengan P2 didapatkan nilai $p=0,022$, antara kelompok $\mathrm{K}(+)$ dengan $\mathrm{P} 1$ dengan nilai $\mathrm{p}=$ 0,472, antara kelompok $\mathrm{K}(+)$ dengan $\mathrm{P} 2$ dengan nilai $p=0,646$, antara kelompok $P 1$ dan $\mathrm{P} 2$ dengan nilai $\mathrm{p}=0,792$, menunjukkan tidak terdapat perbedaan secara bermakna.

Dari hasil tes ini dapat disimpulkan tidak terdapat pengaruh pemberian ekstrak anggur laut (Caulerpa racemosa var. cylindracea) terhadap $\mathrm{pH}$ lambung dan duodenum tikus putih (Rattus norvegicus) yang diinduksi indometasin. 
Pengaruh Ekstrak Anggur Laut terhadap pH Lambung dan duodenum pada Rattus norvegicus... Ardilon Raxel Faruwu, Riami, Fitri Handajani

\section{PEMBAHASAN}

Pada penelitian, $\mathrm{pH}$ lambung dan duodenum Rattus norvegicus kelompok tanpa perlakuan (K-) dan kelompok induksi indometasin $(\mathrm{K}+)$ menunjukkan adanya perbedaan yang bermakna. Pemberian indometasin pada Rattus norvegicus selama 7 hari dengan dosis $30 \mathrm{mg} / \mathrm{KgBB}$ ini dapat menyebabkan peningkatan asam lambung yang ditandai terjadinya gastritis. $\mathrm{Hal}$ ini diduga akibat pemberian indometasin yang berperan bekerja menghambat COX khususnya COX-1 (Hawkey, 2001). COX adalah enzim pengkatalis reaksi dari asam arakidonat menjadi prostaglandin. Prostaglandin merupakan suatu mediator proinflamasi. COX-1 di epitel lambung berfungsi menghasilkan prostaglandin untuk meregulasi pengeluaran bikarbonat. Bikarbonat pada lambung berperan sebagai buffer terhadap pH lambung. (Matsui et al, 2011; Maaten et al, 2016).

Penurunan bikarbonat menimbulkan gangguan keseimbangan $\mathrm{pH}$ lambung meningkatkan sintesis $\mathrm{HCl}$. Sintesis $\mathrm{HCl}$ menyebabkan $\mathrm{pH}$ lambung menjadi rendah. Selanjutnya $\mathrm{pH}$ lambung yang rendah menyebabkan proteolysis pada mukosa lambung dan bila keadaan berlanjut, dapat mengakibatkan kerusakan pada sel lambung dan memicu proses inflamasi. (Amrulloh and Utami, 2016; Song et al, 2020; Tarique et al, 2016).
Berdasarkan hasil penelitian, terdapat perbedaan bermakna pada $\mathrm{pH}$ lambung antara kelompok K (-) dengan $\mathrm{K}(+)$ dengan nilai $p=0,005$. Hal ini diduga akibat induksi indometasin 30mg/KgBB menyebabkan penurunan $\mathrm{pH}$ duodenum menjadi lebih asam. Pada duodenum terjadi sekresi senyawa alkali yang berasal dari kantung empedu sehingga $\mathrm{pH}$ duodenum meningkat. Peningkatan ini sebagai akibat dari induksi indometasin. Hal ini dapat dilihat melalui $\mathrm{pH}$ duodenum (K-) kelompok kontrol negatif lebih rendah bandingkan dengan $(\mathrm{K}+)$ kelompok tanpa pelakuan.

Tidak terdapat perbedaan antara $\mathrm{pH}$ lambung kelompok K (-) dengan P1 dengan nilai $p=0,73$. Hal ini disebabkan karena rata rata kedua kelompok hampir sama. Ini memberi makna bahwa kandungan flavonoid anggur laut (Caulerpa racemosa var. cylindracea) bersifat sebagai antioksidan dan anti-inflamasi. Flavonoid yang ada juga membantu memperbaiki sistem pertahan fisiologis terhadap paparan asam lambung. (Handajani, 2019; Nursandi, 2014). Antioksidan dan flavonoid dari anggur laut (Caulerpa racemosa var. cylindracea) berfungsi memulihkan lambung dan memperbaiki sistem pertahanan fisiologis. Dengan demikian sekresi bikarbonatnya dapat menaikan $\mathrm{pH}$ lambung mendekati normal dikisaran 2-4 (Im et al, 2013). 
Terdapat perbedaan yang bermakna pH lambung antara kelompok K (-) dengan P2 dengan nilai $p=0,020$. Keadaan ini menunjukkan bahwa peningkatan dosis eskstrak anggur laut (Caulerpa racemosa var. cylindracea) tidak memberikan hasil yang baik mendekati $\mathrm{pH}$ lambung normal. Pada penelitian ini penggunaan dosis yang tinggi justru merusak, karena asam askorbat yang dikandungnya dapat menurunkan $\mathrm{pH}$ lambung (Lee et al, 2018).

Tidak terdapat perbedaan signifikan $\mathrm{pH}$ lambung antara $\mathrm{K}(+)$ dengan $\mathrm{P} 1$ meskipun hasil pengukuran rerata $\mathrm{pH}$ lambung mengalami peningkatan. Selanjutnya tidak ada perbedaan antara kelompok P1 dengan $\mathrm{K}(-)$ karena $\mathrm{pH}$ lambung mendekati kelompok tanpa perlakuan. Ini memberi makna bahwa antioksidan yang terdapat pada ekstrak anggur laut (Caulerpa racemosa var. cylindracea) dengan dosis $1 \mathrm{~g} / 100 \mathrm{gBB}$ dapat memperbaiki fungsi lambung setelah diinduksi indometasin (Djapiala et al, 2013).

Tidak terdapat perbedaan yang bermakna pada rerata $\mathrm{pH}$ lambung antara kelompok $\mathrm{K}(+)$ dengan $\mathrm{P} 2$, hal ini disebabkan karena asam askorbat dari ekstrak anggur laut (Caulerpa racemosa var. cylindracea) dengan dosis $2 \mathrm{~g} / 100 \mathrm{~g}$ BB memiliki kandungan lain yang justru menimbulkan penurunan rerata $\mathrm{pH}$ lambung. Selanjutnya tidak terdapat perbedaan antara kelompok P1 dengan P2, meskipun pada hasil pengukuran rerata $\mathrm{pH}$ lambung pada P2 lebih rendah dari P1. Dapat disimpulkan pemberian dosis $2 \mathrm{~g} / 100 \mathrm{~g}$ BB kurang efektif untuk meningkatkan $\mathrm{pH}$ lambung. Rendahnya rerata $\mathrm{pH}$ pada P2 diduga akibat adanya senyawa asam askorbat dalam anggur laut (Fithriani, 2015). Dengan demikian pemberian dosis tinggi lebih menurunkan rerata $\mathrm{pH}$ lambung dibandingkan kelompok P1 (Lee et al, 2018).

Pada penelitian ini pemberian ekstrak anggur laut (Caulerpa racemosa var. cylindracea) tidak mempengaruhi rerata $\mathrm{pH}$ lambung secara bermakna dalam uji statistika. Meskipun terdapat perubahan pada pengukuran $\mathrm{pH}$ lambung.

Dari dosis bisa disimpulkan bahwa pemberian dosis $1 \mathrm{~g} / 100 \mathrm{~g}$ BB pada kelompok P1 dapat menaikan rerata $\mathrm{pH}$ lambung. Sebaliknya tidak ada pengaruh pemberian dosis $2 \mathrm{~g} / 100 \mathrm{~g}$ BB pada kelompok P2. Dosis 1g/100g BB dapat dikembangkan dan diteliti kembali dan berpotensi dalam menaikan rerata pada $\mathrm{pH}$ lambung. Penelitian ini memiliki kemiripan kandungan antioksidan dengan penelitian ekstrak bayam merah (Amaranthus tricolor L) dari Hanafi et al (2014), yaitu sama-sama memiliki efek sitoprotektif terhadap lambung. 
Pengaruh Ekstrak Anggur Laut terhadap pH Lambung dan duodenum pada Rattus norvegicus... Ardilon Raxel Faruwu, Riami, Fitri Handajani

Pada penelitian ini pemberian ekstrak anggur laut terhadap $\mathrm{pH}$ duodenum kelompok kontrol (+) menurun secara signifikan akibat induksi indometasin dibanding kelompok kontrol (), meskipun $\mathrm{pH}$ nya masih dalam kisaran $\mathrm{pH}$ netral. Hal ini karena pada duodenum disekresikan senyawa yang bersifat alkali dari kandungan empedu namun belum mampu meredam penurunan $\mathrm{pH}$ dari lambung dan netralisir keasamnan akibat induksi indometasin. Selanjutnya pemberian ekstrak anggur laut tidak mengakibatkan peningkatan $\mathrm{pH}$ yang bermakna pada kelompok perlakuan dibandingkan kelompok kontrol (+), meskipun rerata $\mathrm{pH}$ duodenum sudah mencapai kisaran $\mathrm{pH}$ netral. Pemberian ekstrak anggur laut, mampu merangsang sekresi senyawa dalam kandungan empedu yang bersifat alkali dan mampu meningkatkan $\mathrm{pH}$ duodenum dan menetralisir keasaman yang ditimbulkan oleh induksi indometasin.

\section{KESIMPULAN}

Induksi indometasin $30 \mathrm{mg} / \mathrm{kg} \quad \mathrm{BB}$ secara intragastrik dapat menurunkan rerata $\mathrm{pH}$ lambung dan duodenum secara bermakna $(p=0,23)$. Pemberian ekstrak anggur laut tidak menunjukkan perbedaan $\mathrm{pH}$ lambung dan duodenum secara bermakna pada tikus yang diinduksi indometasin. Ekstrak anggur laut dosis 1g/100g BB meningkatkan rerata $\mathrm{pH}$ lambung hampir mendekati rerata $\mathrm{pH}$ lambung normal, namun tidak memperngaruhi $\mathrm{pH}$ duodenum.

\section{DAFTAR PUSTAKA}

Amrulloh FM, and Utami N, 2016. Hubungan Konsumsi OAINS terhadap Gastritis. Medical Journal of Lampung University. 5(5): 18-21.

Djapiala FY, Lita, Montolalu ADY, and Mentang F, 2013. Kandungan Total Fenol Dalam Rumput Laut Caulerpa racemosa yang Berpotensi Sebagai Antioksidan. Media Teknologi Hasil Perikanan. $1(2)$.

Drini $M, 2017$. Peptic ulcer disease and non-steroidal anti-inflammatory drugs. Australian Prescriber. 40(3): 91-93.

Fithriani D, 2015. Opportunities And Challenges For Developing Caulerpa Racemosa As Functional Foods. The 1st International Symposium on Aquatic Product Precessing 2013. p: 85-96.

Hanafi NA, Sutjiatmo $A B$, and Vikasari SN, 2014. Uji Efek Antitukak Lambung Ekstrak Air Herba Bayam Merah (Amaranthus Tricolor L.) terhadap 
Tikus Wistar Betina. Kartika: Jurnal IImiah Farmasi. 2(1): 45-50.

Handajani F, 2019. Oksidan dan antioksidan pada beberapa penyakit dan proses penuaan. Penerbit: Zifatama Jawara. p: 519.

Hawkey CJ, 2001. COX-1 and COX-2 inhibitors. Best Pract Res Clin Gastoenterol. 15(5): 801-820.

Im WJ, Nam Y, Park SY, and \& Sohn UD, 2013. Gastroprotective Effect Of The Three Glucuronopyranoside Flavonoids In Rats. Korean J Physiol Pharmacol. 17(5): 411415.

Laine L, Takeuchi K, and Tarnawski A, 2008. Gastric Mucosal Defense And Cytoprotection: Bench To Bedside. Gastroenterology. 135(1): 41-60.

Lee JK, Jung SH, Lee SE, Han JH, Jo E et al, 2018. Alleviation of ascorbic acidinduced gastric high acidity by calcium ascorbate in vitro and in vivo. Korean J Physiol Pharmacol. 22(1): 35-42.

Mateen S, Moin S, Khan AQ, Zafar A, and Fatima N, 2016. Increased reactive oxygen species formation and oxidative stress in rheumatoid arthritis. PLOS ONE. 11(4), 1-15.
Matsui H, Shimokawa O, Kaneko T, Nagano $\mathrm{Y}$, Rai K, et al, 2011. The Pathophysiology Of Non-Steroidal Anti-Inflammatory Drug (NSAID)Induced Mucosal Injuries In Stomach And Small Intestine. J Clin Biochem Nutr. 48(2): 107-111. Nursandi NMNJ, 2014. Karakteristik Kimiawi Rumput Laut Lokal (Caulerpa sp.) dan Potensinya sebagai Sumber Antioksidan. Prosiding Seminar Nasional Pengembangan Teknologi Pertanian Politekbik Negeri Lampung. p: 577-584.

Pérez MJ, Falqué $E$, and Domínguez $H$, 2016. Antimicrobial Action Of Compounds From Marine Seaweed. Marine Drugs. 14(3): 52.

Ridhowati S, Asnani, 2016. Potensi Anggur Laut Kelompok Caulerpa racemosa Sebagai Kandidat Sumber Pangan Fungsional Indonesia. Oseana. 41(4): 50-62.

Song $H$, Zeng $M$, Chen X., Chen X, Peng J, 2020. Antiulcerogenic Activity of Li-Zhong Decoction on Duodenal Ulcers Induced by Indomethacin in Rats: Involvement of TLR2/MyD88 Signaling Pathway. Evidence-Based Complementary and Alternative Medicine, 2020. 
Pengaruh Ekstrak Anggur Laut terhadap pH Lambung dan duodenum pada Rattus norvegicus... Ardilon Raxel Faruwu, Riami, Fitri Handajani

Suhartri, Aldi Y, and Maradona A, 2008. Uji Efek Ekstrak Etanol Daun Pepaya (Carica Papaya Linn) Terhadap Tukak Lambung Yang Diinduksi Dengan Etanol Absolut Pada Tikus Putih Betina. Jurnal Sains dan Teknologi Farmasi. 13(2): 1-11.
Tarique $\mathrm{M}$, Siddiqui $\mathrm{HH}$, Khushtar $\mathrm{M}$, and Rahman MA, 2016. Protective Effect Of Hydro-Alcoholic Extract Of Ruta Graveolens Linn. Leaves On Indomethacin And Pylorus Ligation-Induced Gastric Ulcer In Rats. Journal of Ayurveda and Integrative Medicine. 7(1): 38-43. 